Jones, A. S., Marsh, G. E. \& Rizvi, S. B. H. (1957). J. gen. Microbiol. 17, 586-595

\title{
The Isolation and Composition of the Nucleic Acids of Aerobacter aerogenes
}

\author{
By A. S. JONES, G. E. MARSH AND S. B. H. RIZVI
}

Chemistry Department, University of Birmingham

\begin{abstract}
SUMMARY : The nucleic acids were isolated from Aerobacter aerogenes by extraction of mechanically disintegrated organisms with $0 \cdot 14 \mathrm{M}$-sodium chloride at $\mathrm{pH} 7 \cdot 5$. Upon subsequent isolation, about $80 \%$ of the deoxyribonucleic acid (DNA) originally contained in the organisms was obtained, but only about $50 \%$ of the ribonucleic acid (RNA). The loss of RNA was mainly due to enzymic degradation. By extraction of $A$. aerogenes with $1 \%$ sodium cholate at $60^{\circ}$, enzymic degradation was virtually eliminated and a good yield of both DNA and RNA obtained. They were relatively undegraded and both showed evidence of the presence of hydrogen bonds. The amounts of the purine and pyrimidine bases in both types of nucleic acid were determined. The DNA and RNA from the normal streptomycin-sensitive strain of $A$. aerogenes differed significantly in base composition from the corresponding nucleic acids from a strain which had been trained to grow in $5 \%(w / v)$ streptomycin.
\end{abstract}

For the quantitative isolation of relatively undegraded nucleic acids from living cells, two factors are of importance. First, the isolation procedure should be capable of completely extracting the nucleic acids without appreciably modifying them and secondly, enzymic degradation should be eliminated. Existing methods for the isolation of deoxyribonucleic acid (DNA) closely approach this ideal, but, since ribonucleic acid-hydrolysing enzymes are often very stable and difficult to inhibit, these conditions have not been realized in most methods for the isolation of ribonucleic acids (RNA). Thus a number of mild procedures have been developed (Grinnan \& Mosher, 1951; Kay \& Dounce, 1953; Kirby, 1956; Lombard \& Chargaff, 1956), but in these, at some stage, usually during the initial homogenization of the tissue, there might have been enzymic degradation even at the low temperatures used by some of these workers. Other methods (Crestfield, Smith \& Allen, 1955; Dorner \& Knight, 1953) have employed temperatures high enough to break any hydrogen bonds which might be present in native RNA. One of the best procedures so far reported appears to be that of Hunter \& Butler (1956) in which the nucleic acids were extracted from Bacillus megaterium with sodium dodecyl sulphate at room temperature after previous treatment of the organisms with lysozyme. In this method there was the possibility of ribonuclease action during the lysozyme treatment, although the product obtained was biologically active.

The present paper describes a method for the isolation of the nucleic acids from Aerobacter aerogenes under conditions in which ribonucleic acid-hydrolysing enzymes are inhibited. Both DNA and RNA have been isolated in good yield and in relatively undegraded form. The compositions of the two types 
of nucleic acid which have been isolated from a normal strain of $\boldsymbol{A}$. aerogenes and from a strain which had been trained to grow in a high concentration of streptomycin, have been determined.

\section{METHODS}

\section{Growth of organism}

Cultures of Aerobacter aerogenes were grown with aeration at $37^{\circ}$ for $24 \mathrm{hr}$. on the following medium $(\%, w / v)$ : Lab Lemco, 1 ; Oxoid bacteriological peptone, 1 ; sodium chloride, 0.5; and glucose, 1 . Before the addition of the glucose, the medium was adjusted to $\mathrm{pH} 9$, the resulting precipitate filtered off, the filtrate adjusted to $\mathrm{pH} 7$ and sterilized at $10 \mathrm{lb}$./sq.in. for $15 \mathrm{~min}$. The glucose was then added aseptically.

A streptomycin-resistant strain was obtained from the normal strain by repeated subcultivation in the presence of gradually increasing concentrations of the antibiotic. The strain finally obtained grew in $50 \mathrm{mg}$. streptomycin $/ \mathrm{ml}$. The original strain grew at a limiting concentration of $0.001 \mathrm{mg}$. streptomycin/ $\mathrm{ml}$. The streptomycin-resistant strain had similar biochemical reactions to the normal strain. For the isolation of nucleic acids, both strains were grown on the same medium. Nitrogen, phosphorus, pentose and deoxypentose were estimated by methods previously used (Dutta, Jones \& Stacey, 1956). Total carbohydrate was determined by the phenol-sulphuric acid method (Dubois et al. 1951), and protein as described by Lowry, Rosebrough, Farr \& Randall (1951).

\section{Purine and pyrimidine contents of the nucleic acids}

Samples of DNA (5 mg.) were dried at $110^{\circ}$ in vacuo for $2-3 \mathrm{hr}$. and then hydrolysed by heating with anhydrous trifluoroacetic acid $\left(0.2 \mathrm{ml}\right.$.) at $155^{\circ}$ for $60 \mathrm{~min}$. The bases were separated chromatographically on Whatman no. 1 filter paper with the solvent of Wyatt (1951), eluted and estimated spectrophotometrically.

Some difficulty was experienced in effecting the complete hydrolysis of RNA with perchloric acid (see Crosbie, Smellie \& Davidson, 1953) or with trifluoroacetic acid. With the latter reagent, the presence of water $(c .10 \%$, $\mathrm{w} / \mathrm{v}$ ) was essential for complete hydrolysis of the pyrimidine nucleotides. However, the method of Crosbie et al. (1953), in which RNA is hydrolysed with $0.3 \mathrm{~N}$-potassium hydroxide at $37^{\circ}$ and the mononucleotides so produced separated by paper electrophoresis, was found to be superior. The paper electrophoresis was carried out in the apparatus of Foster (1952) as described by Foster, Jones \& Rizvi (1956).

The samples of RNA prepared in this work contained considerable amounts of calcium which caused precipitation of some of the nucleotides in the presence of $0.3 \mathrm{~N}$-potassium hydroxide. Until this was realized, this precipitate was centrifuged off before neutralization with perchloric acid. This gave slightly erroneous results for the proportions of the nucleotides (Cox, Jones, Marsh \& Peacocke, 1956). The procedure finally adopted was to adjust the alkaline digest of the RNA to $\mathrm{pH} 1$ without removing this precipitate. This gave more accurate results. 


\section{RESULTS}

The nucleic acid content of Aerobacter aerogenes

Aerobacter aerogenes was grown as described above, and harvested in the Sharples supercentrifuge. The organisms were washed once with distilled water and suspended in distilled water. The suspension was divided into two equal parts, one of which was freeze-dried to give $1.892 \mathrm{~g}$. dry organisms. This material was then analysed by Schmidt \& Thannhauser's (1945) method ('Table 1).

Table 1. The distribution of phosphorus-containing compounds in Aerobacter aerogenes

\begin{tabular}{lc}
\multicolumn{1}{c}{ in Aerobacter aerogenes } & $\begin{array}{c}\text { Phosphorus } \\
(\mu \text { mole/g. }\end{array}$ \\
& dry wt. organism) \\
Inorganic acid-soluble phosphorus & $11 \cdot 7$ \\
Organic acid-soluble phosphorus & $\mathbf{7 0 \cdot 2}$ \\
Lipid phosphorus & $\mathbf{7 3 \cdot 0}$ \\
Deoxyribonucleic acid phosphorus & $\mathbf{3 \cdot 3}$ \\
Ribonucleic acid phosphorus & $\mathbf{3 8 0}$ \\
Phosphoprotein phosphorus & $16 \cdot 6$ \\
Fraction insoluble in N-sodium hydroxide & $13 \cdot 4$
\end{tabular}

The very low value obtained for DNA was due to the difficulty experienced in centrifuging down the DNA precipitate produced by acidification of the $\mathrm{N}$-sodium hydroxide digest (cf. Mitchell \& Moyle, 1954). Other experiments gave a higher value for DNA, but the exact value depended upon the conditions of centrifugation. $\mathbf{A}$ better result was obtained by estimation of the deoxypentose by Dische's diphenylamine reaction (Dische, 1930) in a hot trichloroacetic acid extract of organisms obtained by Schneider's (1945) method. Interference with the estimation by other colour-producing substances was decreased by measuring the difference between the optical density at $600 \mathrm{~m} \mu$. and that at $700 \mathrm{~m} \mu$.

These results showed that Aerobacter aerogenes contained $15 \%(\mathrm{w} / \mathrm{w})$ nucleic acids (assuming a phosphorus content for the nucleic acids of $8 \%(w / w))$ and that $18 \%$ of this was DNA and $82 \%$ RNA. Recent work (Jones, Rizvi \& Stacey, unpublished results) has shown that this value for RNA is too high because of the presence of other phosphorus-containing compounds in the RNA fraction. An exact determination of these was not carried out on this particular culture, but from other results it was concluded that about 25-30\% of the phosphorus in the RNA fraction was due to other phosphorus-containing substances.

\section{Isolation of the nucleic acids from Aerobacter aerogenes}

The other half of the suspension of organisms was shaken with ballotini glass balls $(1.0 \mathrm{~mm}$. diameter $)$ in the presence of $0.01 \mathrm{M}$-sodium arsenate at $0^{\circ}$ for 6-7 hr. The broken organisms were extracted at $0^{\circ}$ for $18 \mathrm{hr}$. with $0.001 \mathrm{M}$-sodium arsenate at $\mathrm{pH}$ 7. The suspension was decanted from the glass 
balls and a $20 \%$ (w/v) aqueous solution of cetrimide (Cetavlon, I.C.I. [Pharmaceuticals] Ltd., Manchester) added until precipitation was complete. The precipitate, which contained nucleic acids, proteins and acidic polysaccharides was centrifuged off, dissolved in M-sodium chloride and the solution diluted with three volumes of water. This procedure precipitated the nucleic acids and part of the protein but left in solution the acidic polysaccharides and the rest of the protein. Two repetitions of this precipitation procedure removed the acidic polysaccharides from the precipitate. Protein was removed from the nucleic acid-containing fraction by treatment with chloral hydrate in $2.5 \mathrm{M}$ sodium chloride as previously described (Jones \& Marsh, 1954). From the equivalent of $1.892 \mathrm{~g}$. freeze-dried organisms, $65 \mathrm{mg}$. of white fibrous nucleic acid $(\mathbf{P}, 8.0 \%$ ) was obtained, of which $55 \%$ was DNA. The recovery of DNA was therefore $70 \%$ and that of RNA only about 15-20\%.

Part of the loss of RNA was due to adsorption on the cell debris, the chloral hydrate precipitate and the chloroform-protein gels. This material was recovered by extraction with aqueous $2 \%(\mathrm{w} / \mathrm{v})$ sodium dodecyl sulphate to give $63 \mathrm{mg}$. of nucleic acid, of which $90 \%$ was RNA. The total recovery of DNA was about $80 \%$, therefore, and of RNA about $50 \%$. The rest of the RNA had been lost because of enzymic degradation during the disintegration of the organisms. This was shown by the presence of large quantities of dialysable ultraviolet-absorbing material in the extracts of the disintegrated organisms.

The nucleic acid-hydrolysing enzymes of Aerobacter aerogenes

Organisms from a $24 \mathrm{hr}$. culture of Aerobacter aerogenes (2 1.) were harvested in the Sharples supercentrifuge and disintegrated by shaking a thick suspension with ballotini glass balls ( $1 \mathrm{~mm}$. diam.) at $0^{\circ}$ for $3 \mathrm{hr}$. the $\mathrm{pH}$ value being maintained at $7 \cdot 5$. The cell debris was removed by centrifugation at $15,000 \mathrm{~g}$ and the supernatant liquid diluted with acetate buffer to $\mathrm{pH} 6.0$ and ionic strength $0 \cdot 1$ with respect to acetate.

A sample of this extract was diluted five times with acetate buffer $(\mathrm{pH} \mathrm{6}$; ionic strength $0 \cdot 1$ ) and incubated at $37^{\circ}$. At intervals, samples (1 ml.) were removed and mixed with $\mathrm{M}$-calcium chloride in ethanol $(0.5 \mathrm{ml}$.). (This reagent quantitatively precipitated unhydrolysed Aerobacter aerogenes-RNA.) The solutions were centrifuged, the supernatant liquids diluted five times with distilled water and the optical density at $260 \mathrm{~m} \mu$. measured. The results (Fig. 1) indicated that there was rapid hydrolysis of the nucleic acids in the extract.

This extract was allowed to stand at $37^{\circ}$ for $5 \mathrm{hr}$. and then dialysed. The material remaining in the cellophan bag was almost free from nucleic acid but contained an enzyme capable of hydrolysing Aerobacter aerogenes-RNA. The activity of this enzyme was determined against $A$. aerogenes-RNA $(0.5 \mathrm{mg} . /$ ml.) in acetate buffer pH 6 (ionic strength $0 \cdot 1$ ) at $37^{\circ}$. The results (Fig. 1) showed that the enzyme was activated at $37^{\circ}$ by $0.3 \mathrm{M}$-sodium chloride, but inhibited by $8 \mathrm{M}$-sodium chloride. It was more active at $60^{\circ}$ than at $37^{\circ}$, and at $60^{\circ}$ it was inhibited by $1 \%(\mathrm{w} / \mathrm{v})$ sodium cholate. Other results indicated that the enzyme was inhibited at $37^{\circ}$ by $0 \cdot 1 \%(\mathrm{w} / \mathrm{v})$ sodium dodecyl sulphate. 


\section{Extraction of the nucleic acids from Aerobacter aerogenes by $1 \%$ sodium cholate at $60^{\circ}$}

A suspension of Aerobacter aerogenes (the equivalent of $5 \mathrm{~g}$. of freeze-dried organisms suspended in $150 \mathrm{ml}$. water adjusted to $\mathrm{pH} 7-7 \cdot 5)$ was added slowly to an equal volume of $2 \%(\mathrm{w} / \mathrm{v})$ sodium cholate $(\mathrm{pH} 7-7 \cdot 5)$ containing $0 \cdot 14 \mathrm{M}$ sodium chloride, maintained at $63^{\circ}$. During the addition of the suspension, the temperature was not allowed to fall below $60^{\circ}$. The mixture was kept at this temperature for $2 \mathrm{hr}$., cooled to $0^{\circ}$ and diluted 4-5 times by prolonged

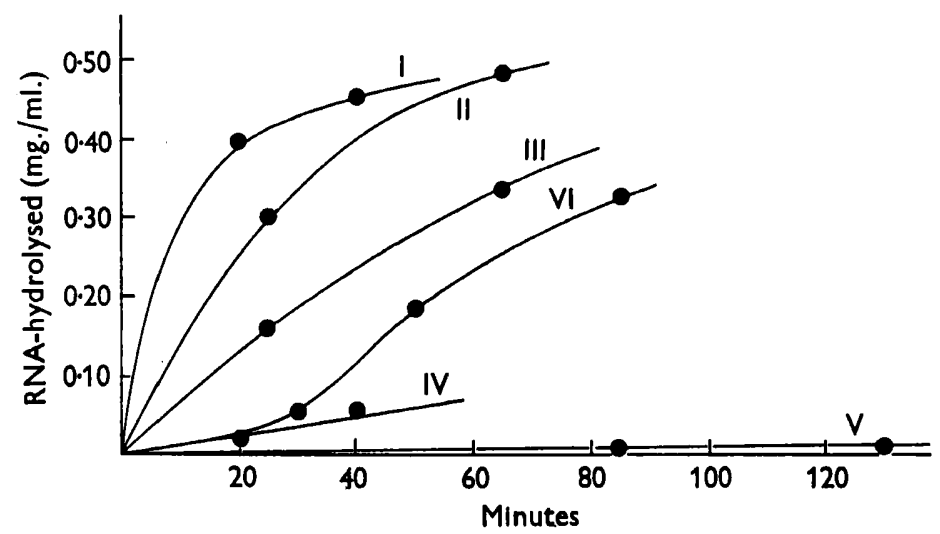

Fig. 1. Activity of the ribonucleic acid-hydrolysing enzymes of Aerobacter aerogenes. I-V: hydrolysis of Aerobacter aerogenes RNA in acetate buffer (pH 6; ionic strength $0 \cdot 1$ ); I, at $60^{\circ}$; II, at $37^{\circ}$ in the presence of $0.3 \mathrm{M}$-sodium chloride; III, at $37^{\circ}$; IV, at $37^{\circ}$ in the presence of $3 M$-sodium chloride; $V$ at $60^{\circ}$ in the presence of $1 \%(\mathrm{w} / \mathrm{v})$ sodium cholate and $0.07 \mathrm{~m}$-sodium chloride. VI: hydrolysis of the nucleic acids proceeding at $37^{\circ}$ in an extract of disintegrated Aerobacter aerogenes in acetate buffer (pH 6 ; ionic strength, $0 \cdot 1$ ).

stirring at $0^{\circ}$ with $0 \cdot 14 \mathrm{M}$-sodium chloride. Cell debris was then centrifuged off at $14,000 \mathrm{~g}$ and extracted with successive portions of $0 \cdot 14 \mathrm{M}$-sodium chloride (adjusted to $\mathrm{pH} 7$ with sodium bicarbonate) until no more nucleic acid was extracted (10-12 washings were usually necessary). The combined extract and washings were adjusted to $0.25 \mathrm{M}$ with sodium chloride, cetrimide added until precipitation was complete. The procedure was then as shown in Fig. 2.

The final products had the following analysis (carried out on moist material): DNA (140 mg.); N, $11.2 \% ; P, 6.58 \% ; N / P 1 \cdot 70$. RNA content, $3 \% ;(\epsilon)_{P}$, 6350. RNA (588 mg.); N, 12.3 \% ; P, 7.13\%; N/P, 1.72; DNA content, $1.1 \%$ $(\epsilon)_{P}, 7720$.

The samples of DNA isolated by the above method had rather low phosphorus contents $(8 \cdot 0-8 \cdot 5 \%$ on dried material) compared with the theoretical value of $9 \cdot 3 \%$. The RNA samples were fairly pure (theoretical phosphorus content, $8.94 \%$ ), although the presence of $2-3 \%$ protein and the same amount of carbohydrate (other than D-ribose) was detected. The impurity in the DNA probably came from the Cetavlon, since the use of a purer product (introduced by I.C.I. Pharmaceuticals Ltd. during the progress of this work) gave nucleic acids with a phosphorus content $>9 \%$. 


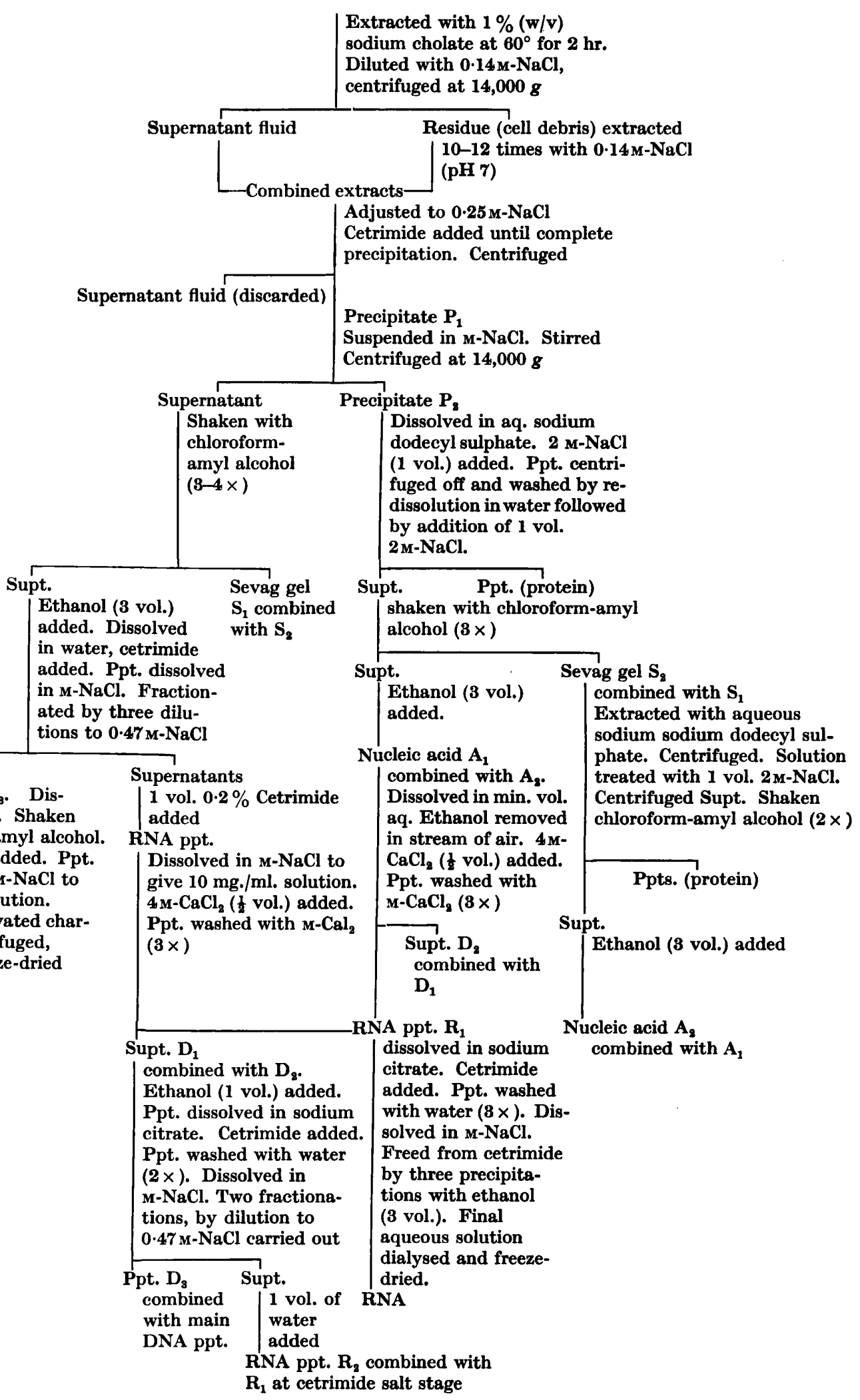

Fig. 2. Procedure for the isolation of the nucleic acids from the sodium cholate extract of Aerobacter aerogenes. 
The sugar component of the RNA was identified as D-ribose by hydrolysis with $4 \mathrm{~N}$-sulphuric acid followed by paper electrophoresis at $\mathrm{pH} 10$ in borate buffer and paper chromatography in butanol/ethanol/water/ammonia (sp.gr. $0 \cdot 880)$ mixture, $(40: 10: 49: 1)$.

The RNA was slightly fibrous although it contained only about $1 \%$ DNA. The DNA was fibrous and upon acidification to $\mathrm{pH} 2$ and readjustment to $\mathrm{pH} 7$ showed a $16 \%$ increase in optical density at $260 \mathrm{~m} \mu$. This increase was of a similar order to that obtained with herring roe DNA which had been isolated by a very mild procedure (Laland, Lee, Overend \& Peacocke, 1954).

\section{Composition of the nucleic acids}

Samples of the DNA and RNA from a normal and a streptomycin-resistant strain of Aerobacter aerogenes were analysed for their purine and pyrimidine contents. Three samples were isolated from each strain and each sample was analysed in duplicate. The results are shown in Table 2 . The recovery of bases was 3.9 and 3.8 mole $/ 4 \mathrm{~g}$. atom phosphorus for DNA and RNA, respectively.

Table 2. Purine and pyrimidine contents of the nucleic acids of Aerobacter aerogenes

Purine and pyrimidine content (mols. per 100 nucleotides)

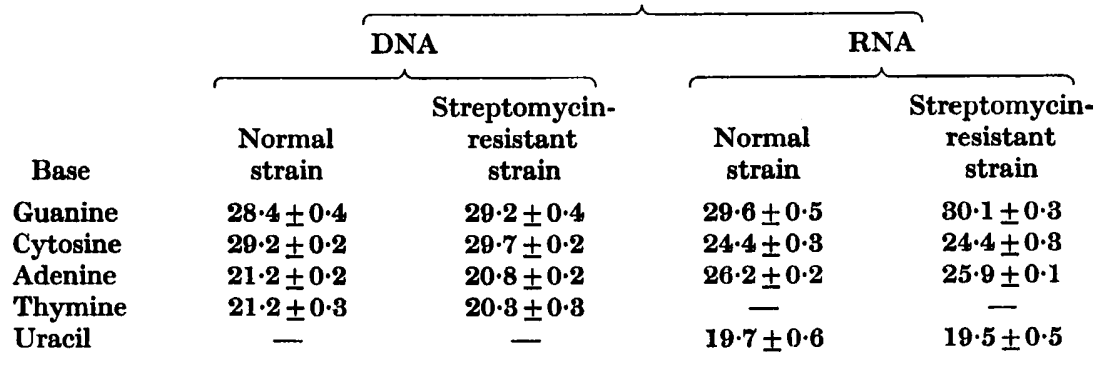

The results (Table 2) show that the composition of the DNA from the two strains differed from each other with respect to all four bases, while the RNA from the two strains differed from each other with respect to guanine, adenine and uracil. The significance of these differences was estimated by the usual methods of statistical analysis, the results of which are given in Table 3.

Table 3. Analysis of variance for the data of Table 2

\begin{tabular}{|c|c|c|c|c|}
\hline \multirow[b]{2}{*}{ Base } & \multicolumn{2}{|c|}{ DNA } & \multicolumn{2}{|c|}{ RNA } \\
\hline & $\boldsymbol{F}$ & $\boldsymbol{P}$ & $F$ & $\boldsymbol{P}$ \\
\hline Guanine & $12 \cdot 8$ & $<0.01$ & 4.45 & $<0.10$ \\
\hline Cytosine & 9.94 & $<0.02$ & - & - \\
\hline Adenine & 24-0 & $<0.001$ & $6 \cdot 44$ & $<0.05$ \\
\hline Thymine & 15.8 & $<0.01$ & - & - \\
\hline Uracil & - & - & $<1$ & - \\
\hline
\end{tabular}

The differences in composition between the DNA from the normal strain and that from the streptomycin-resistant strain were highly significant. In the 
case of RNA the differences in the guanine and adenine contents were just significant but the difference of the uracil contents was not significant.

The statistical calculations were checked by Mr Morley-Jones, Statistician in the Agricultural Research Council Unit of Biometrical Genetics, University of Birmingham.

\section{DISCUSSION}

The isolation of the nucleic acids from Aerobacter aerogenes was complicated by the presence of hydrolytic enzymes which, particularly in the case of RNA, caused extensive degradation during the disintegration of the bacteria even when this was carried out at $0^{\circ}$. This may have been due in part to the local heating which would occur during the collisions of the glass balls. Since the hydrolytic enzymes were inhibited by $0 \cdot 1 \%(\mathrm{w} / \mathrm{v})$ sodium dodecyl sulphate at $37^{\circ}$ or by $1 \%(w / v)$ sodium cholate at $60^{\circ}$, the use of these reagents for the isolation of the nucleic acids was investigated.

Aqueous $2 \%$ sodium dodecyl sulphate readily lysed Aerobacter aerogenes at room temperature, and thus liberated the nucleic acids. However, since much denatured protein was also extracted and the presence of this made difficult the subsequent isolation of pure nucleic acids, this reagent was not used. Henry \& Stacey (1946), however, found that sodium cholate at $60^{\circ}$ extracted nucleic acids from Gram-positive organisms without extracting large quantities of protein. Also sodium deoxycholate has been used to extract a biologicallyactive DNA from pneumococci after previous heat treatment at $65^{\circ}$ (Avery, Macleod \& McCarty, 1944). Under these conditions of extraction hydrogen bonds of the type found in DNA should be left intact (Cox \& Peacocke, 1956).

When applied to Aerobacter aerogenes this method resulted in the isolation of about $85 \%$ of the DNA and $90 \%$ of the RNA. The DNA was fibrous, gave viscous solutions and showed evidence of the presence of hydrogen bonds. Evidence, from titration studies, has already been presented to show that the RNA also contains hydrogen bonds (Cox et al. 1956).

In the DNA the amounts of guanine and adenine were equivalent to the amounts of cytosine and thymine respectively. As with most bacteria, the amount of guanine + cytosine was in excess of adenine +thymine. In the RNA, the amount of adenine + cytosine was approximately equal to that of guanine + uracil, a regularity shown by a number of ribonucleic acids (Elson, Trent \& Chargaff, 1955; Elson \& Chargaff, 1955).

The compositions of the DNA from the streptomycin-resistant strain showed small but significant differences from that of the DNA of the normal streptomycin-sensitive strain. Differences in the biological activity of DNA from streptomycin-resistant strains as compared with DNA from sensitive strains have been reported (e.g. Alexander \& Leidy, 1953) and this demonstration of a chemical difference is of interest in this connexion. The differences in composition of the RNA from the two strains were less significant. These results may be compared with those previously obtained with Sarcina lutea (Dutta, et al. 1956) in which a difference in composition of RNA, but not of DNA, from a streptomycin-resistant strain as compared with the corresponding nucleic acids from a sensitive strain, was detected. It appears therefore that by 
training certain organisms to grow in the presence of streptomycin, changes in the composition of the nucleic acids can result. The commonly accepted mechanism of this change, is, in the case of streptomycin, the selection, in the presence of the drug, of a resistant mutant (Eagle \& Saz, 1955).

The authors wish to thank Professor M. Stacey, F.R.S., for his close interest, Mrs S. S. Topaz for technical assistance, and the Medical Research Council for financial support.

\section{REFERENCES}

Alexander, H. E. \& Leidy, G. (1953). Induction of streptomycin resistance in sensitive Haemophilus influenzae by extracts containing deoxyribonucleic acid from resistant $H$. influenzae. J. exp. Med. 97, 17.

Avery, O. T., Macleod, C. M. \& McCarty, M. (1944). Chemical nature of the substance inducing transformation of pneumococcal types. Induction of transformation by a deoxyribonucleic acid fraction isolated from pneumococcus type III. J. exp. Med. 79, 137.

Cox, R. A., Jones, A. S., Marsh, G. E. \& Peacocke, A. R. (1956). On hydrogen bonding and branching in a bacterial ribonucleic acid. Biochim. biophys. Acta, 21, 576.

Cox, R. A. \& Peacocke, A. R. (1956). Electrometric titration of the sodium salts of deoxyribonucleic acids. Part IV. Denaturation by heat in aqueous solution. J. chem. Soc. p. 2646.

Crestfield, A. M., Smith, K. C. \& Allen, F. W. (1955). The preparation and characterisation of ribonucleic acids from yeast. J. biol. Chem. 216, 185.

Crosbie, G. W., Smelite, R. M. S. \& Davidson, J. N. (1953): Phosphorus compounds in the cell. V. Composition of the cytoplasmic and nuclear ribonucleic acids of the liver cell. Biochem. J. 54, 287.

Dische, Z. (1930). Utber einige neue charakteristische Farbreaktionen der Thymonucleinsäure und eine Mikromethode zur Bestimmung derselben in tierischen Organen mit Hilfe dieser Reaktionen. Mikrochemie, 8, 4.

Dorner, R. W. \& KNight, C. A. (1953). The preparation and properties of some plant virus nucleic acids. J. biol. Chem. $205,959$.

Dubois, M., Gilles, K., Hamilton, J. K., Rebers, P. A. \& Smith, F. (1951). A colorimetric method for the determination of sugars. Nature, Lond. 168, 167.

Dutta, S. K., Jones, A. S. \& Stacey M. (1956)., The nucleic acids of Sarcina lutea. J. gen. Microbiol. 14, 160.

Eagle, H. \& SAz, A. K. (1955). Antibiotics. Annu. Rev. Microbiol. 9, 200.

Elson, D. \& Chargaff, E. (1955). Evidence of common regularities in the composition of pentosenucleic acid. Biochim. biophys. Acta, $17,367$.

Elson, D., Trent, L. W. \& Chargaff, E. (1955). The nucleotide composition of pentosenucleic acids in different cellular fractions. Biochim. biophys. Acta, 17, 362.

Foster, A. B. (1952). A simplified apparatus for filter paper ionophoresis. Chem. $d$ Ind. p. 1050.

Foster, A. B., Jones, A. S. \& Rizvi, S. B. H. (1956). Ionophoresis of nucleic acid components. Chem. \& Ind. p. 914.

Grinnan, E. L. \& Mosher, W. A. (1951). Highly polymerised ribonucleic acid. Preparation from liver and depolymerisation. J. biol. Chem. 191, 719.

Henry, H. \& Stacey, M. (1946). Histochemistry of the Gram staining reaction for micro-organisms. Proc. Roy. Soc. B, 133, 391.

Hunter, G. D. \& Butler, J. A. V. (1956). Stimulation by ribonucleic acid of induced $\beta$-galactosidase formation in Bacillus megaterium. Biochim. biophys. Acta, 20, 406. 
Jones, A. S. \& MARsh, G. E. (1954). The deproteinisation of nucleoproteins. Biochim. biophys. Acta, 14, 559.

KAY, E. R. M. \& Dounce, A. L. (1953). The preparation of sodium ribonucleate with the use of sodium dodecyl sulphate. J. Amer. chem. Soc. 75, 4041.

KrrBY, K. S. (1956). A new method for the isolation of ribonucleic acids from mammalian tissues. Biochem. J. 64, 405.

Laland, S. G., Lee, W. A., Overend, W. G. \& Peacocke, A. R. (1954). The ultraviolet absorption of some degraded deoxyribonucleic acids. Biochim. biophys. Acta, 14, 356.

Lombard, A., \& Chargaff, E. (1956). The pentosenucleic acid of Azotobacter vinelandii. Biochim. biophys. Acta, 20, 585.

Lowry, O. H., Rosebrough, N. J., Farr, A. L. \& Randalx, R. J. (1951). Protein measurement with the Folin phenol reagent. J. biol. Chem. 193, 265.

Mitchell, P. \& Moyle, J. (1954). The Gram reaction and cell composition: Nucleic acids and other phosphate fractions. J. gen. Microbiol. 10, 533.

Schmidt, G. \& Thannhauser, S. J. (1945). A method for the determination of deoxyribonucleic acid, ribonucleic acid and phosphoproteins in animal tissues. J. biol. Chem. $161,88$.

Schneider, W. C. (1945). Phosphorus compounds in animal tissues. I. Extraction and estimation of deoxypentosenucleic acid and pentosenucleic acid. J. biol. Chem. 161, 293.

Wyatr, G. R. (1951). The purine and pyrimidine composition of deoxypentosenucleic acids. Biochem. J. 48, 584.

(Received 23 April 1957) 